Article

\title{
Temporal and cultivar-specific effects on potato root- and rhizosphere fungal diversity
}

\author{
Kaire Loit 1,*, Liina Soonvald ${ }^{1}$, Alar Astover ${ }^{2}$, Eve Runno-Paurson ${ }^{1,3}$, Maarja Öpik ${ }^{4}$ and Leho \\ Tedersooo $^{5}$
}

1 Institute of Agricultural and Environmental Sciences, Estonian University of Life Sciences. Fr. R. Kreutzwaldi 1, 51006 Tartu, Estonia

2 Chair of Soil Science, Institute of Agricultural and Environmental Sciences, Estonian University of Life Sciences. Fr. R. Kreutzwaldi 1, 51006 Tartu, Estonia

3 Chair of Crop Science and Plant Biology, Institute of Agricultural and Environmental Sciences, Estonian University of Life Sciences, Fr. R. Kreutzwaldi 1, 51006 Tartu

4 Department of Botany; University of Tartu, 40 Lai St., 51005 Tartu, Estonia

5 Department of Mycology and Microbiology; University of Tartu; Ravila 14a; 50411 Tartu, Estonia

* Correspondence: Kaire.Loit@emu.ee

\begin{abstract}
The rhizosphere fungal community can play an important role in determining plant growth and health. In this study, using high-throughput sequencing, we investigated the fungal diversity and community composition in the roots and rhizosphere soil of 21 potato (Solanum tuberosum L.) cultivars. The samples were collected at three different sampling points. Furthermore, we assessed the differences in both diversity and composition of pathogen and saprotroph communities. In soil and roots, the fungal richness and relative abundance of pathogens and saprotrophs were mainly affected by sampling time. However, root fungal communities were also significantly affected by cultivar. The most substantial effect of cultivar was on root pathogen diversity. Moreover, the occurrence of most pathogens strongly varied among cultivars. Soil fungal community composition was primarily determined by sampling time; whereas in roots, the primary determinant was cultivar. Our results demonstrate changes in fungal communities over the potato growing season, as well as highlight the importance of potato cultivar on root fungal communities, and emphasise their importance in plant breeding.
\end{abstract}

Keywords: Solanum tuberosum; agroecosystems; high-throughput sequencing; fungal guild, fungal diversity; host specificity; potato cultivars

\section{Introduction}

Modern agriculture has increased crop yields significantly; however, it often relies on chemical fertilisers and pesticides, and thus can negatively impact the environment [1], including soil ecosystems [2]. Soil harbours millions of microorganism species, many of which form intimate associations with plant roots [3], [4]. One study has described these associations as direct and indirect, direct being mutualistic and pathogenic associations with plants, and indirect being the action of freeliving microbes that affect nutrient availability in the surrounding environment [5]. All these mechanisms can affect plant productivity.

In agricultural fields, plant-associated-and saprotrophic microbial communities are affected by different management practices such as crop rotation, fertilisation and tillage [6], [7], [8], [9], [10]. Plant species, as well as plants at different growth stages, may also harbour distinct microbial communities [11], [12], [13]. Furthermore, plants modify their associated- and surrounding microbial communities by exuding organic compounds into the surrounding environment, which act as nutrient sources for microbes [14], [15]. Higher fertilisation rates may increase root exudation as well 
as microbial abundance. Since breeding programs are usually conducted at high nutrient levels [4]; [16], it is likely that breeding affects both microorganisms inhabiting the plant-soil interface.

Potato (Solanum tuberosum L.) is one of the most important staple crops that can grow in broad climatic conditions, and had a global production of over 368 million tons in 2018 [17]. Regardless of climate, cultivated potatoes are constantly exposed to various pathogens that pose a serious threat to potato production worldwide [18], [19], [20], [21]. Several studies have focused on individual pathogens of potato [22], [23], [19]. However, to our knowledge, there are a lack of community-level data regarding other putative hazardous soil-borne pathogens, as well as genotypic differences in biotic stress resistance in potato plants. Screening and selecting plant genotypes that would resist pathogens, and even associate with beneficial microbes, may improve the health and yield of this important crop [16], [24].

The objective of this study was to assess differences in fungal community structure, both within roots and in rhizosphere soil, of 21 potato cultivars. Our goal was to examine the relationship between plant genotype and associated fungal guilds (saprotrophic fungi, pathogenic fungi and arbuscular mycorrhizal fungi), as well as overall fungal community composition, over the growing season. We postulated two hypotheses: 1) fungal guilds differ in their responses to potato genotype, and 2) fungal guild composition and diversity differ among plant growth stages.

\section{Materials and Methods}

\subsection{Study site}

The study site was located at Einola Farm (58 17'02.0 "N 26³'19.6"E) in Reola, Tartu County, Estonia. The study was conducted under a conventionally managed farming system from May to September 2014, according to the following practices: primary tillage by moldboard plowing (with straw addition) in late autumn, secondary tillage in early spring, seedbed preparation by harrowing and furrowing in early spring, and hilling, which was conducted three times during the growing season. No irrigation was used. The climate of the study area is characterised as a transitional climate zone between maritime and continental. In 2014, the mean annual temperature was $7.1^{\circ} \mathrm{C}$, with the annual rainfall being $592 \mathrm{~mm}$ [25]. At the study site, winter wheat (Triticum aestivum L.), spring wheat (T. aestivum), rapeseed (Brassica napus L.), spring wheat and potato have been grown in succession since 2010. Twenty-one cultivars of potato were grown in a randomised block design with three replicate plots per cultivar, each containing 23 certified seed tubers (Table S1) that were stored at $3-$ $4{ }^{\circ} \mathrm{C}$. Tubers were kept at $10-15^{\circ} \mathrm{C}$ for three weeks before being planted into the bottom of the furrow on 15 May. Detailed information about field operations is shown in Table S2.

\subsection{Soil chemical analysis}

During planting, three subsamples of soil were collected from $0-20 \mathrm{~cm}$ depth from each plot. All samples were air-dried, sieved to $<2 \mathrm{~mm}$ and pooled to obtain one composite sample for each plot. Soil chemical analyses were carried out to assess soil plant-available (ammonium lactate extraction method [26]) phosphorus $(\mathrm{P})$, potassium $(\mathrm{K})$, magnesium $(\mathrm{Mg})$ and calcium $(\mathrm{Ca})$ content, as well as soil pНкс. Total nitrogen $(\mathrm{N})$ and carbon $(\mathrm{C})$ content of air-dried samples were determined by dry combustion, using a varioMAX CNS elemental analyser (ELEMENTAR, Germany). Soil parameters are indicated in Table S3.

\subsection{Sampling and DNA extraction}

Root samples were collected at the early flowering stage (BBCH 60-62) and during senescence (BBCH 93-95) [27]. Cultivars were classified as early-, medium- or late-maturing, based on their maturity period. Maturity classes comprised eight early-, seven intermediate- and six late-maturing cultivars (See Table S1 for list of cultivars). Based on the different flowering time of potato cultivars, root samples were collected on 9 July, 16 July and 22 July. During the plant senescence stage (SSC), root samples of all cultivars were collected on 26 August. The root systems of three individual plants from each plot were randomly chosen and collected using a clean shovel. Root material was transported to the laboratory in a cooler. Upon arrival, roots were washed three times with deionised water to remove residual soil, dried at $70{ }^{\circ} \mathrm{C}$ for $48 \mathrm{~h}$, and stored airtight at room temperature until molecular analysis. Rhizosphere soil samples were collected three times over the study period: 
during planting (BEM), and again during flowering (FL) and senescence (SSC), simultaneously with root sampling. Each sample consisted of three subsamples of soil taken randomly from the potato root zone at $0-25 \mathrm{~cm}$ depth. The subsamples were pooled, dried at $50{ }^{\circ} \mathrm{C}$ for $48 \mathrm{~h}$, mixed thoroughly and subjected to molecular analysis.

Total DNA was extracted from $0.075 \mathrm{~g}$ dry weight of roots and $0.2 \mathrm{~g}$ dry weight of rhizosphere soil, using the PowerSoil DNA Isolation Kit (MO BIO Laboratories Inc., Carlsbad, CA, USA), following manufacturer's instructions with the following modifications: 1) samples were homogenised via bead beating with three $3 \mathrm{~mm}$ autoclaved steel beads for $5 \mathrm{~min}$ at $30 \mathrm{~Hz}$, using a MixerMill MM400 (Retsch, Haan, Germany); and 2) final elution was performed twice with $50 \mu 1$ solution C6.

\subsection{PCR amplification and high-throughput sequencing}

The ITS2 region was amplified using ITS3mix1-5 (mixture of six forward primers in equimolar concentration analogous to ITS3) and a degenerate reverse primer ITS4ngs, which was tagged with one of the 108 indexes [28]. PCR amplification was performed in a $25 \mu \mathrm{l}$ reaction volume, and consisted of $18 \mu \mathrm{L}$ nuclease-free water, $5 \mu \mathrm{L} 5 \mathrm{x}$ HOT FIREPol Blend Mastermix (10mM MgCl2) (Solis Biodyne, Tartu, Estonia), $0.5 \mu \mathrm{L}$ of each primer ( $20 \mathrm{pmol})$ and $1 \mu \mathrm{L}$ DNA extract. PCR was performed using Eppendorf 5341 and Eppendorf 6321 thermal cyclers (Eppendorf AG, Hamburg, Germany) in four replicates, under the following thermocycling conditions: $15 \mathrm{~min}$ at $95{ }^{\circ} \mathrm{C}, 35$ cycles of $30 \mathrm{~s}$ at $95^{\circ} \mathrm{C}, 30 \mathrm{~s}$ at $55^{\circ} \mathrm{C}, 1 \mathrm{~min}$ at $72{ }^{\circ} \mathrm{C}$ and $10 \mathrm{~min}$ at $72{ }^{\circ} \mathrm{C}$. PCR products were pooled, and their relative quantities were estimated by running $5 \mu \mathrm{L}$ of amplicon DNA on $1 \%$ agarose gel (SeaKem LE Agarose, Lonza Group Ltd, Basel) for 15 min. To obtain sufficient PCR product, DNA samples yielding no visible band, and samples with a very strong band, were re-amplified by respectively increasing or reducing the number of cycles. The quantities of PCR products were normalised with SequalPrep Normalisation Plate Kit (Invitrogen, Carlsbad, CA). All samples were sequenced in an Illumina MiSeq $2 \times 300$ bp paired-end run at the Estonian Genome Center (University of Tartu).

\subsection{Bioinformatics}

Paired-end sequencing ( 2 × $300 \mathrm{bp}$ ) in the Illumina MiSeq sequencer resulted in 772,326 reads. Sequencing reads were quality-filtered and assigned to samples using mothur 1.34.4 [29] (average quality over $15 \mathrm{bp} \geq 26$, and no ambiguities allowed). The quality-trimmed data were assembled using PANDAseq Assembler [30], with a minimum overlap of $15 \mathrm{bp}$, and demultiplexed in mothur. Potential chimeric sequences were removed using USEARCH 7.0.1090 [31]. The remaining sequences with primer artefacts were excluded using Unix commands. The ITS2 subregion was extracted using ITSx 1.0.9 [32], and clustered using a 97\% similarity threshold in CD-HIT [33]. Singleton OTUs were removed from further analyses. Representative sequences for BLASTn search were picked in mothur using the abundance method. Also, BLASTn searches were performed for the representative sequence of each OTU against the UNITE reference dataset v7.0 [34]. OTUs were further checked and filtered based on BLASTn search values as well as positive and negative controls to remove contaminants, non-fungal OTUs, potential artefacts and index-switching errors. OTUs with $75 \%, 80 \%$, $85 \%, 90 \%, 95 \%$, and $97 \%$ sequence similarity thresholds were considered to represent phylum, class, order, family, genus, and species level, respectively [28]. Based on taxonomic assignments, OTUs were parsed to one of the following functional groups of fungal guilds: plant pathogenic fungi, saprotrophic fungi and arbuscular mycorrhizal fungi, based on FUNGuild [35]. OTUs not assigned to plant pathogens by FUNGuild, but reported as potato pathogens according to the United States Department of Agriculture (USDA) Agricultural Research Service (https://nt.arsgrin.gov/fungaldatabases/), were additionally assigned as pathogens. Raw data of this study is available through the Sequence Read Archive, BioProject PRJNA638263.

\subsection{Statistical analysis}

We calculated linear regression between number of obtained OTUs per sample and square root of the obtained sequences per sample, in order to control for variation in sequencing depth [28]. In the case of significant relationships, standardised residuals of OTU richness were used as a proxy for fungal richness. The relative abundance of fungal guilds was calculated as a number of sequences 
corresponding to the particular guild divided by the total number of fungal sequences for each sample.

Differences in richness- and relative abundance of total fungal communities, as well as those of fungal guilds, were tested using GLM (Type III SS) followed by Tukey HSD post-hoc tests $(\alpha=0.05$; Statistica 12.0, Palo Alto, CA, USA). Explanatory variables included potato cultivar, plant growth stage (fixed factor with levels BEM, FL, SSC), time $x$ cultivar interaction, and replicate block (random factor with three levels). PERMANOVA+ [36], implemented in Primer 7 software (PRIMER-E, Auckland, New Zealand), was used to study the community composition of both the overall fungal community, as well as that of separate fungal guilds, both rhizosphere- and root-associated. Three samples (LK129, LK130 and LK131) were removed from rhizosphere total fungal- and saprotroph datasets, as they contained significantly lower amounts of sequences and OTUs, compared to other samples. PERMANOVA+ tests were carried out with 9999 permutations under the reduced model. The read abundance was standardised by samples and fourth-root transformed before calculating the Bray-Curtis similarity index. Adjusted $R^{2}$ values were calculated using the function RsquareAdj in the package "vegan" in R 3.6.0 (R Development Team, http://www. R-project.org). Trends in fungal composition were visualised via non-metric multi-dimensional scaling (NMDS) ordinations, as implemented in the metaMDS function in both "vegan" and "ggplot" packages. 
Table 1. Effects of cultivar, sampling time, and cultivar $\mathrm{x}$ sampling time interaction on the richness of all fungi, saprotrophic fungi, and plant pathogenic fungi in rhizosphere soil and roots.

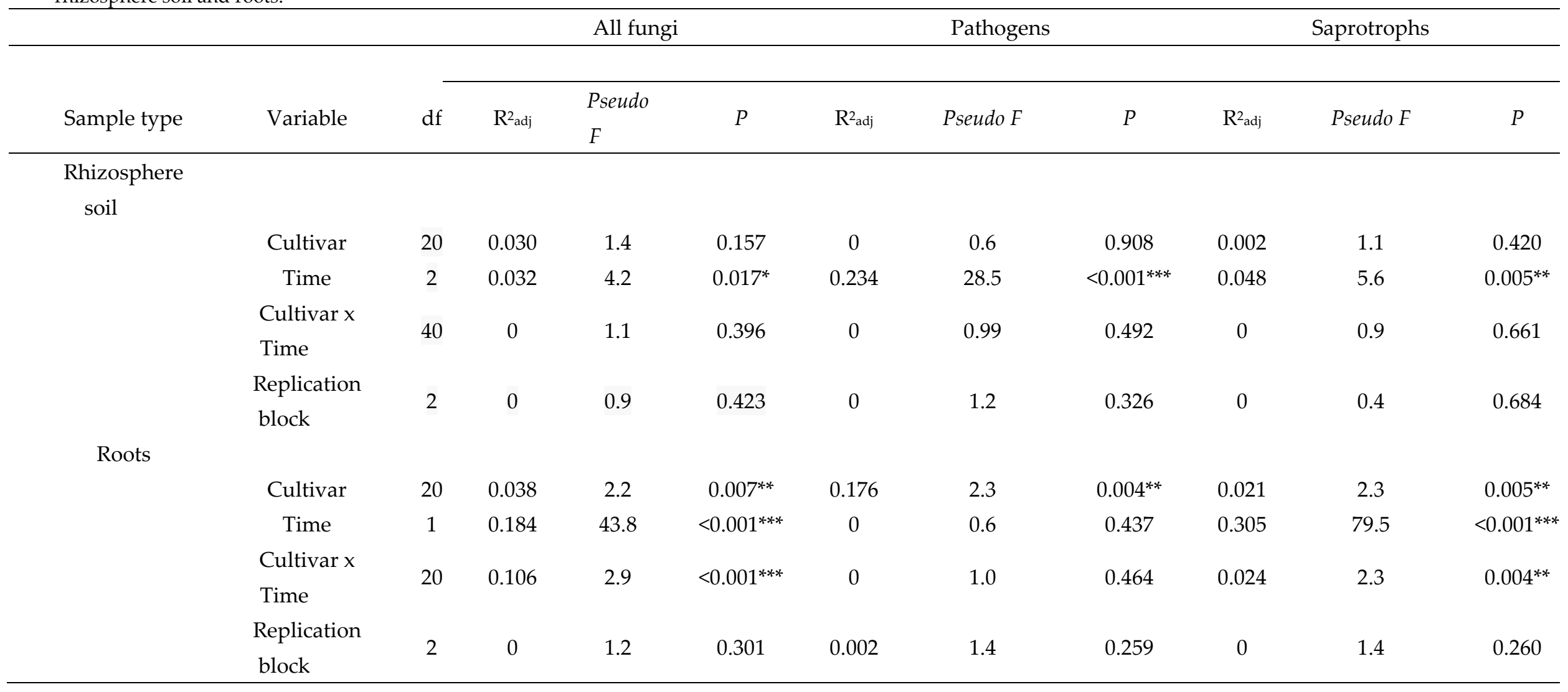

$* * * \mathrm{p}<0.001 ; * * \mathrm{p}<0.01 ; * \mathrm{p}<0.05$.

$d f$, degrees of freedom; $\mathrm{R}^{2}$ adj, adjusted $\mathrm{R}^{2} ;$ Pseudo $F$, pseudo-F statistic; $P$, calculated probability. 
6 of 19

Table 2. Effects of cultivar, sampling time, and cultivar $\mathrm{x}$ sampling time interaction on the relative abundance of plant pathogenic fungi and saprotrophic fungi in rhizosphere soil and roots.

\begin{tabular}{|c|c|c|c|c|c|c|c|c|}
\hline \multirow[b]{2}{*}{ Sample type } & \multirow[b]{2}{*}{ Variable } & \multirow[b]{2}{*}{$\mathrm{df}$} & \multicolumn{3}{|c|}{ Pathogens } & \multicolumn{3}{|c|}{ Saprotrophs } \\
\hline & & & $\mathrm{R}^{2}$ adj & Pseudo F & $P$ & $\mathrm{R}^{2}$ adj & Pseudo F & $P$ \\
\hline \multicolumn{9}{|l|}{ Rhizosphere soil } \\
\hline & Cultivar & 20 & 0.011 & 1.7 & $0.043^{*}$ & 0.012 & 1.7 & $0.039^{*}$ \\
\hline & Time & 2 & 0.250 & 37.7 & $<0.001^{* * *}$ & 0.273 & 41.0 & $<0.001^{* * *}$ \\
\hline & Cultivar $\mathrm{x}$ Time & 40 & 0 & 1.4 & 0.068 & 0 & 1.2 & 0.223 \\
\hline & Replication block & 2 & 0 & 0.8 & 0.459 & 0 & 1.3 & 0.278 \\
\hline & Time & 1 & 0.296 & 66.8 & $<0.001^{* * *}$ & 0.242 & 46.7 & $<0.001^{* * *}$ \\
\hline & Cultivar $\mathrm{x}$ Time & 20 & 0 & 1.1 & 0.333 & 0 & 1.0 & 0.423 \\
\hline & Replication block & 2 & 0.048 & 7.0 & $0.002^{* *}$ & 0.019 & 3.3 & $0.042^{*}$ \\
\hline
\end{tabular}

$d f$, degrees of freedom; $\mathrm{R}^{2}$ adj, adjusted $\mathrm{R}^{2} ;$ Pseudo $F$, pseudo-F statistic; $P$, calculated probability.

$* * * \mathrm{p}<0.001 ; * * \mathrm{p}<0.01 ; * \mathrm{p}<0.05$ 
Table 3. Differences in total fungal, pathogenic and saprotrophic community composition in both rhizosphere soil and roots of different potato cultivars.

\begin{tabular}{|c|c|c|c|c|c|c|c|c|c|c|c|}
\hline \multirow[b]{2}{*}{ Sample type } & \multirow[b]{2}{*}{ Variable } & \multirow[b]{2}{*}{$\mathrm{df}$} & \multirow[b]{2}{*}{$R^{2} a d j$} & \multirow[b]{2}{*}{ Pseudo F } & \multicolumn{2}{|c|}{ All fungi } & \multicolumn{3}{|c|}{ Pathogens } & \multicolumn{2}{|c|}{ Saprotrophs } \\
\hline & & & & & $P$ & $\mathrm{R}^{2} \mathrm{adj}$ & Pseudo F & $P$ & $\mathrm{R}^{2} \mathrm{adj}$ & Pseudo F & $P$ \\
\hline \multicolumn{12}{|l|}{ Rhizosphere soil } \\
\hline & Cultivar & 20 & 0.008 & 1.183 & $<0.001^{* * *}$ & 0.004 & 1.135 & 0.144 & 0.014 & 1.260 & $<0.001^{* * *}$ \\
\hline & Time & 2 & 0.062 & 4.758 & $0.002^{* *}$ & 0.102 & 9.125 & $0.004^{* *}$ & 0.058 & 4.302 & $0.004^{*}$ \\
\hline & Replication block & 2 & 0.007 & 1.858 & $<0.001^{* * *}$ & 0.0109 & 2.513 & $0.001^{* *}$ & 0.004 & 1.467 & $0.012^{*}$ \\
\hline & Cultivar x Time & 40 & 0 & 1.007 & 0.409 & 0 & 1.139 & 0.079 & 0 & 0.954 & 0.845 \\
\hline & Cultivar x Field & 40 & 0 & 1.016 & 0.299 & 0 & 1.132 & 0.087 & 0 & 0.981 & 0.655 \\
\hline & Time $x$ Field & 4 & 0.009 & 1.586 & $<0.001^{* * *}$ & 0.003 & 1.438 & 0.053 & 0.010 & 1.621 & $<0.001^{* * *}$ \\
\hline \multicolumn{12}{|l|}{ Roots } \\
\hline & Cultivar & 20 & 0.082 & 1.823 & $<0.001^{* * *}$ & 0.130 & 2.485 & $<0.001^{* * *}$ & 0.057 & 1.399 & $0.001^{* *}$ \\
\hline & Time & 1 & 0.053 & 7.863 & 0.102 & 0.077 & 13.088 & 0.098 & 0.0331 & 4.994 & 0.105 \\
\hline & Replication block & 2 & 0.012 & 2.223 & $<0.001^{* * *}$ & 0.004 & 1.689 & $0.040^{*}$ & 0.009 & 1.938 & $0.003^{* *}$ \\
\hline & Cultivar $\mathrm{x}$ Time & 20 & 0.013 & 1.392 & $<0.001^{* * *}$ & 0.004 & 1.378 & $0.004^{* *}$ & 0.001 & 1.280 & $0.004^{* *}$ \\
\hline & Cultivar x Field & 40 & 0 & 1.020 & 0.362 & 0 & 0.916 & 0.793 & 0 & 1.179 & $0.011^{*}$ \\
\hline & Time $x$ Field & 2 & 0 & 1.253 & 0.105 & 0 & 1.088 & 0.369 & 0 & 1.284 & 0.132 \\
\hline
\end{tabular}

$d f$, degrees of freedom; $\mathrm{R}^{2}$ adj, adjusted $\mathrm{R}^{2} ;$ Pseudo- $F$, pseudo-F statistic; $P$, calculated probability.

$* * * \mathrm{p}<0.001 ; * * \mathrm{p}<0.01 ; * \mathrm{p}<0.05$ 


\section{Results}

The quality-filtered sequence dataset comprised 224,195 high quality, full length ITS2 reads in 315 samples, with an average number of 712 sequences per sample. These sequencing reads were assigned to 1655 fungal OTUs, with in roots 80 OTUs in roots and 110 OTUs in rhizosphere soil per sample on average (Table S4). The highest proportion of OTUs was assigned to Ascomycota (38.7\%), followed by Basidiomycota (21.7\%), Chytridiomycota (11.2\%) and Glomeromycota (4.7\%) (Fig. S1). In roots, Ascomycota dominated during both FL stage and SSC stage (Figure 1A). Furthermore, Ascomycota prevailed in each cultivar's roots (Figure 2A), except cultivars Merlot and Solist, where Basidiomycota prevailed (Figure 2A). In rhizosphere soil, Mortierellomycota dominated in BEM stage and FL stage, whereas Ascomycota dominated in SSC stage (Figures 1B, 2B).

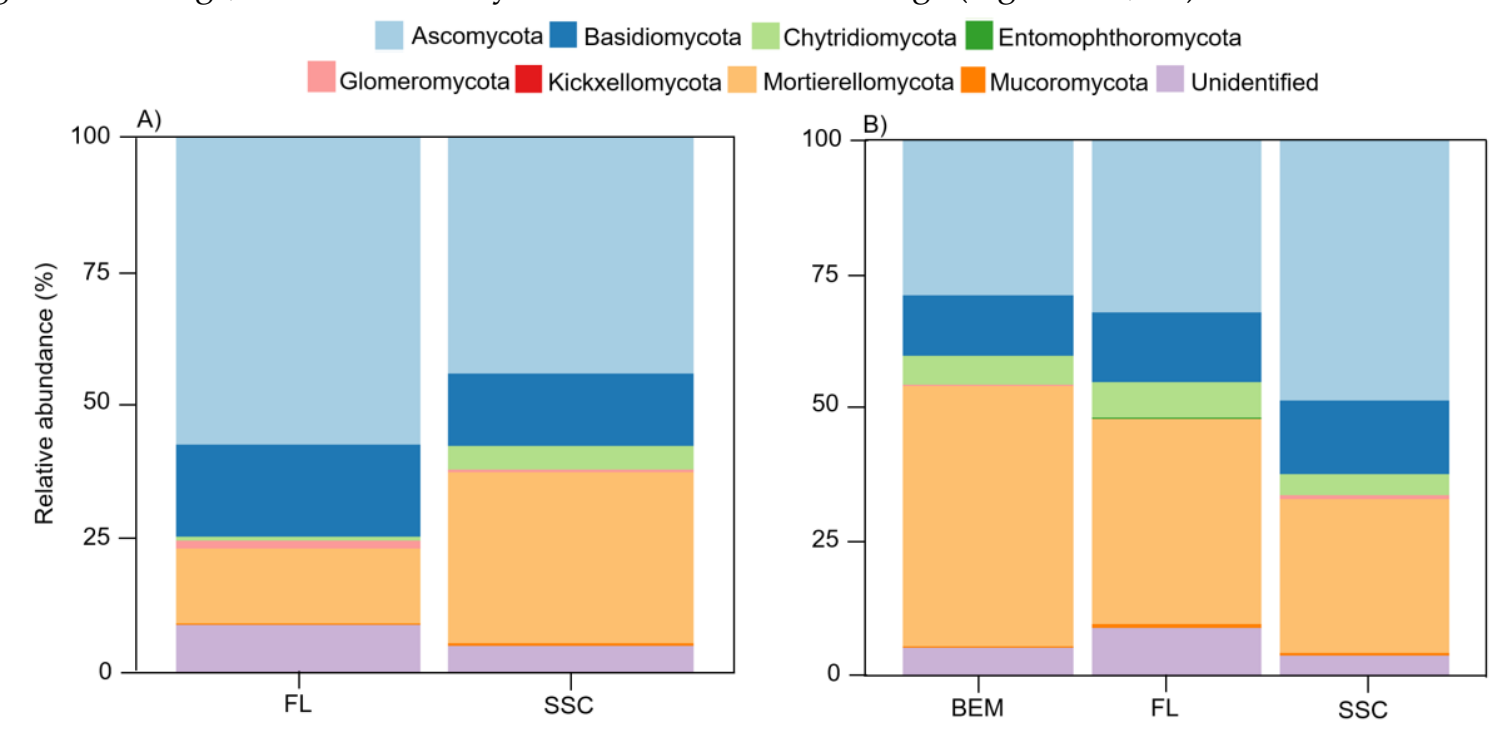

Figure 1. Taxonomic composition of root (A) and rhizosphere (B) fungal communities in different sampling times. BEM, before emergence; FL, flowering stage; SSC, senescence stage.

Of all sequences, $24.1 \%$ were assigned to plant-pathogenic fungi, whereas saprotrophic fungi and arbuscular mycorrhizal fungi accounted for $44 \%$ and $0.6 \%$ of sequences, respectively. Similar patterns occurred in root- and rhizosphere samples. Due to their lack of detection from several samples, diversity patterns of arbuscular mycorrhizal fungi are not reported. 


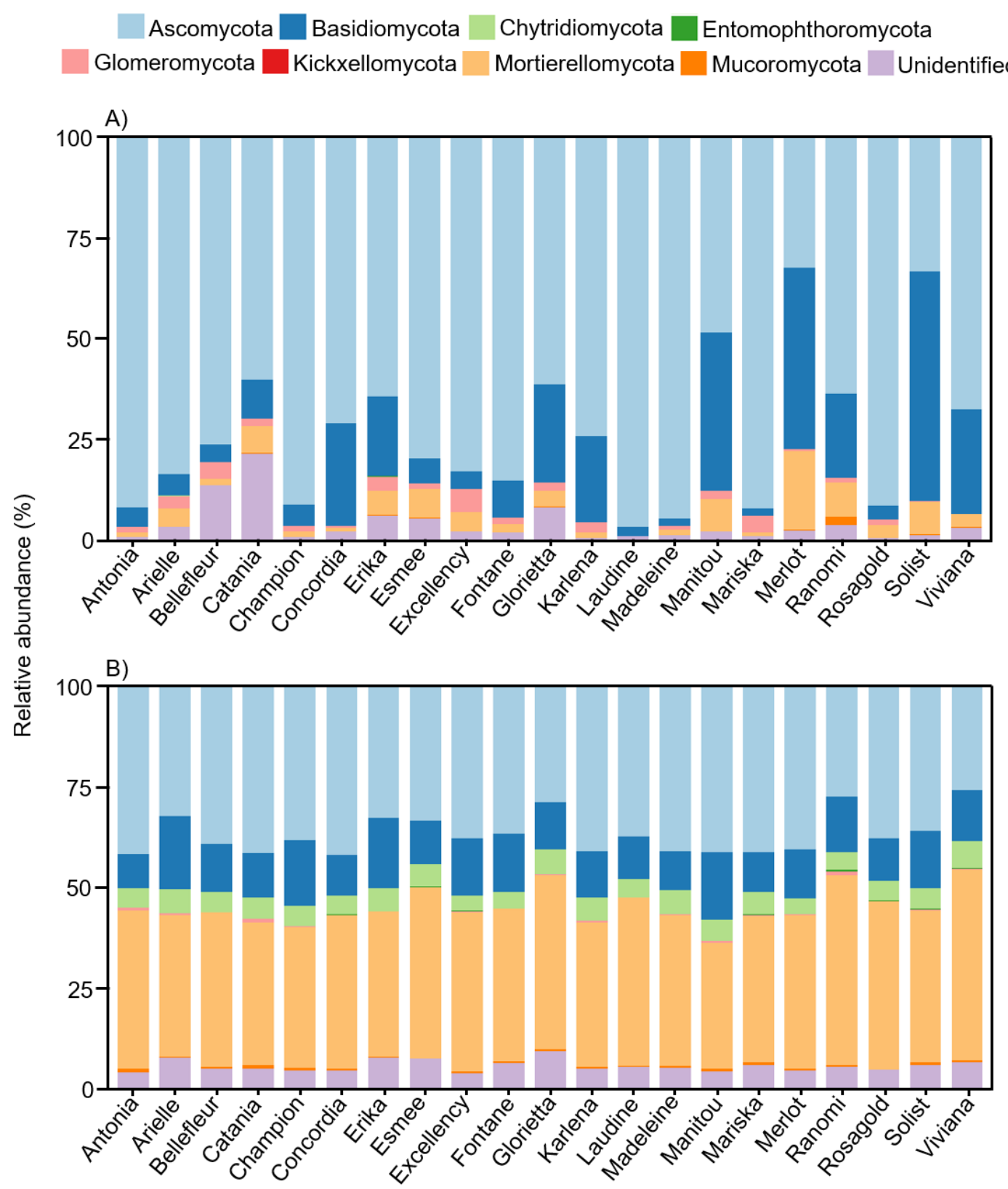

Figure 2. Taxonomic composition of root- (A) and rhizosphere (B) fungal communities in different potato cultivars.

\subsection{Richness of fungal guilds}

The highest proportion of variance in root fungal richness was explained by sampling time $\left(\mathrm{F}_{1,82}\right.$ $=43.75, \mathrm{R}^{2} \mathrm{adj}=0.184, \mathrm{P}<0.001$; Table 1$)$, followed by the sampling time $\mathrm{x}$ cultivar interaction $\left(\mathrm{F}_{20,82}=\right.$ 2.85, $\mathrm{R}^{2}$ adj $\left.=0.106, \mathrm{P}<0.001\right)$ and cultivar $\left(\mathrm{F}_{20,82}=2.20, \mathrm{R}^{2} \mathrm{adj}=0.038, \mathrm{P}=0.007\right)$. Post-hoc analyses showed that the cultivar Merlot had significantly higher total fungal richness than cultivars Concordia, Solist and Laudine (Figure 3A); and revealed that in FL stage, Merlot had significantly higher root fungal richness than most other cultivars, except Manitou, Excellency, Glorietta, Viviana, Esmee, Erika and Arielle. There were no significant differences among pairwise comparisons during SSC stage (Table S5). Rhizosphere soil fungal richness was explained only by sampling time $\left(\mathrm{F}_{2,124}=\right.$ $4.20, \mathrm{R}^{2} \mathrm{adj}=0.032, \mathrm{P}=0.017$; Table 1$)$, with significantly higher values during plant SSC stage than BEM stage (Table S5). 
Root-pathogenic fungal richness was explained only by cultivar $\left(\mathrm{F}_{20,82}=2.30, \mathrm{R}^{2}\right.$ adj $=0.176, \mathrm{P}=$ 0.004; Table 1). Post-hoc analyses showed that the cultivar Glorietta had significantly higher pathogen richness than the cultivars Viviana, Concordia and Solist, with no significant differences among other pairwise comparisons (Figure 5B). In contrast, rhizosphere soil pathogen richness was explained only by sampling time $\left(\mathrm{F}_{2,124}=28.50, \mathrm{R}^{2} \mathrm{adj}=0.234, \mathrm{P}<0.001\right.$; Table 1$)$, with SSC stage exhibiting higher richness compared to BEM- and FL stages (Table S6).

Root saprotroph richness was highest in the FL stage $\left(\mathrm{F}_{1,82}=79.50, \mathrm{R}^{2} \mathrm{adj}=0.305, \mathrm{P}<0.001\right.$; Table 1$)$; and cultivar $\left(\mathrm{F}_{20,82}=2.30, \mathrm{R}^{2} \mathrm{adj}=0.021, \mathrm{P}=0.005\right)$ and sampling time $\mathrm{x}$ cultivar interaction $\left(\mathrm{F}_{20,82}=2.30\right.$, $R^{2} a d j=0.126, P=0.004$; Table 1) both also showed significant effect. Post-hoc analyses showed that the cultivar Merlot had significantly higher saprotroph richness than Concordia and Laudine, with no significant differences among other pairwise comparisons (Figure 3C). In contrast, rhizosphere soil saprotroph richness was explained only by sampling time $\left(F_{2,124}=5.60, R^{2} a d j=0.048, P=0.005\right.$; Table 1). The highest saprotroph richness was observed during plant SSC stage, and the lowest value at FL stage (post-hoc, $\mathrm{P}=0.003$; Table S7).

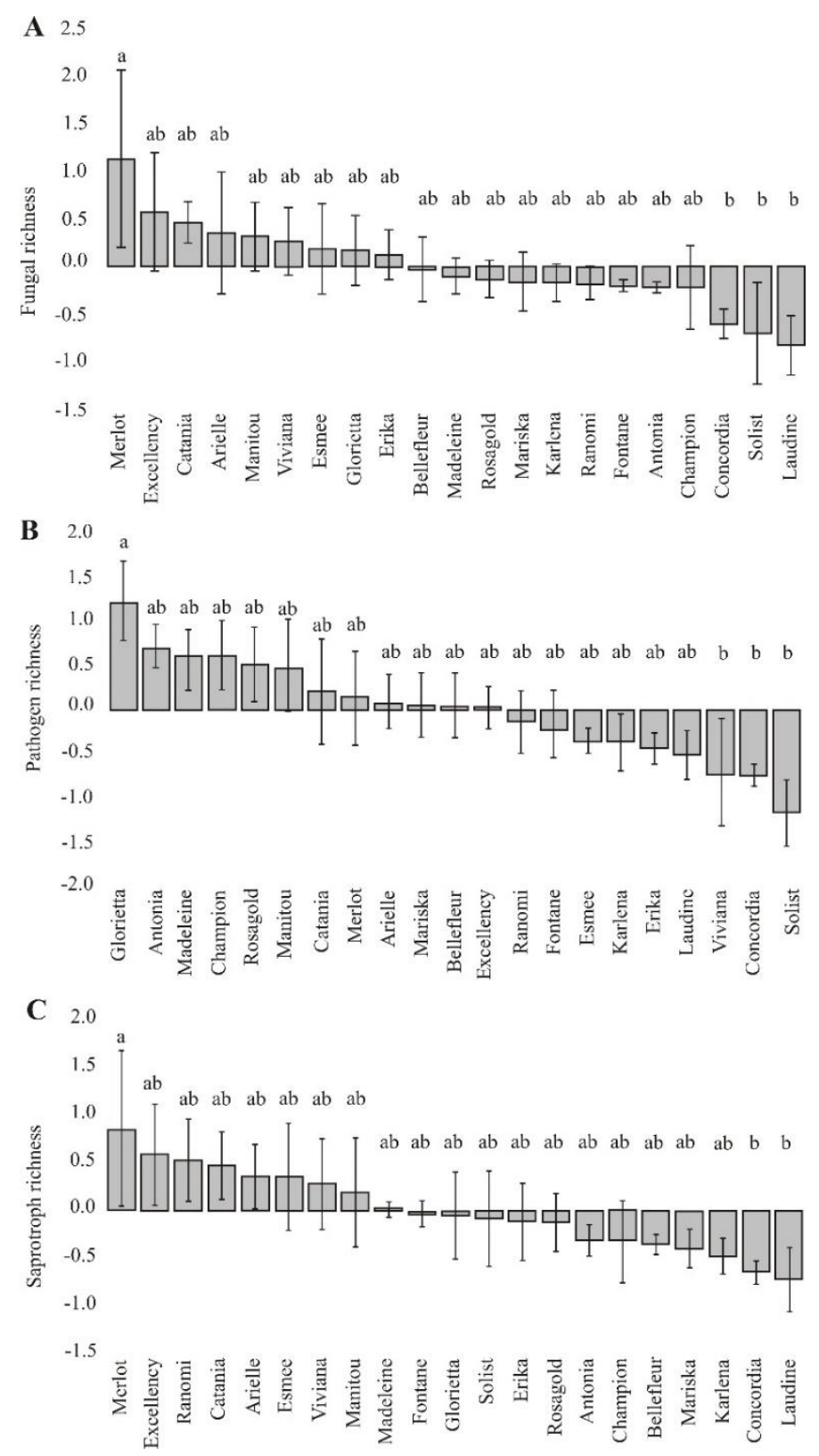

Figure 3. Results of a general linear model estimating the effect of cultivar for root A) overall fungal, B) pathogen, C) saprotroph richness collected within growth season. Different letters indicate statistically significant differences between cultivars $(\mathrm{P}<0.05)$. 


\subsection{Plant pathogen, and saprotroph abundance}

The highest proportion of variance in relative pathogen abundance in roots was explained by sampling time $\left(\mathrm{F}_{1,82}=66.79, \mathrm{R}^{2} \mathrm{adj}=0.296, \mathrm{P}<0.001\right.$; Table 2$)$, with higher relative pathogen abundance in SSC stage compared to FL stage. Cultivar also had a significant effect $\left(F_{20,82}=1.81, R^{2}\right.$ adj $=0.004, P$ =0.033; Table 2), with Rosagold having significantly higher fungal pathogen abundance than Catania (Table S8). Sampling time had the strongest effect on rhizosphere pathogen abundance $\left(\mathrm{F}_{2,124}=37.70\right.$, $\mathrm{R}^{2}$ adj $=0.250, \mathrm{P}<0.001$; Table 2), with highest values at SSC stage, and lowest values at BEM stage (Table S8). Cultivar also had a significant effect on rhizosphere pathogen abundance $\left(\mathrm{F}_{20,124}=1.69\right.$, $\mathrm{R}^{2} \mathrm{adj}=0.011, \mathrm{P}=0.004$; Table 2), which was non-significant in post-hoc analyses (Table S9).

The highest proportion of root saprotroph abundance was explained by sampling time $\left(\mathrm{F}_{1,82}=46.60\right.$, $\mathrm{R}^{2}$ adj $=0.242, \mathrm{P}<0.001$; Table 2) with plant FL stage exhibiting significantly higher saprotroph abundance. Furthermore, sampling time had a significant influence on rhizosphere saprotroph abundance $\left(\mathrm{F}_{2,124}=41.02, \mathrm{R}^{2} \mathrm{adj}=0.273, \mathrm{P}<0.001\right)$ (Table 2). Highest saprotroph abundance was observed at BEM-, compared to that of both FL- (post-hoc; P <0.001; Table S9) and SSC stage (posthoc, $\mathrm{P}<0.001$; Table S9). Cultivar also had a significant influence on rhizosphere saprotroph abundance $\left(\mathrm{F}_{20,124}=1.69, \mathrm{R}^{2} \mathrm{adj}=0.012, \mathrm{P}=0.040\right.$; Table 2$)$. Post-hoc analysis revealed that the cultivar Viviana had significantly higher saprotroph abundance than that of Manitou (Table S9).

\subsection{Factors affecting the abundance of dominant plant pathogens}

In root samples, Plectosphaerella cucumerina (12.7\%), Microdochium spp. (7.2\%), Fusarium spp. (6.2\%) and Rhizoctonia spp. (teleomorph: Thanatephorus spp., 5.2\%) were the most abundant pathogen taxa. Similar to overall pathogen abundance in root samples, sampling time had the strongest influence on the relative abundance of P. cucumerina $\left(\mathrm{F}_{1,82}=66.40, \mathrm{R}^{2} \mathrm{adj}=0.284, \mathrm{P}<0.001\right.$; Table S10), which peaked at SSC stage. Cultivar had a minor effect on $P$. cucumerina abundance (Table S10). Posthoc analyses revealed a marginally stronger abundance in Rosagold and Esmee, compared to Fontane (Table S11). Cultivar had the strongest influence on relative abundance of Rhizoctonia spp. $\left(\mathrm{F}_{20,82}=2.22\right.$, $\mathrm{R}^{2} \mathrm{adj}=0.140, \mathrm{P}=0.006$; Table S10). post-hoc analyses revealed a marginally higher abundance in roots of the cultivars Merlot, Concordia, Solist, Manitou, Karlena and Glorietta, compared to those of Laudine, Rosagold, Excellency, Viviana, Bellefleur, Fontane, Antonia, Mariska, Madeleine, Champion, Esmee, Erika and Arielle, which showed almost no occurrence of Rhizoctonia spp. (Table S11). Rhizoctonia spp. abundance increased with time $\left(\mathrm{F}_{1,82}=7.40, \mathrm{R}^{2} \mathrm{adj}=0.039, \mathrm{P}=0.007\right.$; Table S11).

In rhizosphere soil samples, Gibellulopsis nigrescens (5.2\%), P. cucumerina (2.4\%), Didymellaceae $(1.4 \%)$ and Fusarium spp. $(0.9 \%)$ were the most abundant pathogen taxa. Similar to overall pathogen abundance in root samples, sampling time had the strongest influence on the relative abundance of G. nigrescens $\left(\mathrm{F}_{2}, 124=9.34, \mathrm{R}^{2} \mathrm{adj}=0.071, \mathrm{P}<0.001\right.$; Table S10), with lowest abundance at BEM stage, compared to plant FL- and SSC stage (Table S12). Sampling time affected abundance of P. cucumerina $\left(F_{2,124}=32.70, R_{2} a d j=0.251, P<0.001\right.$; Table S10 $)$ and Didymellaceae $\left(F_{2,124}=10.5, R^{2}\right.$ adj $=0.103, P<0.001$; Table S10). The lowest P. cucumerina abundance was observed at BEM-, compared to FL- and SSC stage (Table S12). Lowest Didymellaceae abundance was observed at both BEM- and FL stage, compared to that of SSC stage (Table S12). In contrast, cultivar was the only significant variable affecting Fusarium spp. abundance $\left(\mathrm{F}_{20,124}=1.70, \mathrm{R}^{2} \mathrm{adj}=0.060, \mathrm{P}=0.040\right.$; Table S10), but post-hoc analyses revealed that Fusarium spp. abundance in rhizosphere soil of the Merlot is only marginally higher than that of Karlena (Table S12).

\subsection{Factors affecting fungal community composition}

In roots, cultivar was the main factor determining overall fungal- $\left(\mathrm{P}<0.001\right.$, adjusted $\mathrm{R}^{2}=0.082$, Figure $4 \mathrm{~A})$, pathogen- $\left(\mathrm{P}<0.001\right.$, adjusted $\mathrm{R}^{2}=0.130$, Figure $\left.4 \mathrm{~B}\right)$ and saprotroph $(\mathrm{P}=0.001$, adjusted $\mathrm{R}^{2}=0.057$, Figure $4 \mathrm{C}$ ) community composition (Table 3). However, in rhizosphere soil, sampling time was the main factor describing overall fungal- $\left(P=0.002\right.$, adjusted $\mathrm{R}^{2}=0.062$, Figure $\left.5 \mathrm{~A}\right)$, pathogen- $\left(P=0.004\right.$, adjusted $R^{2}=0.102$, Figure $\left.5 B\right)$ and saprotroph $\left(P=0.004\right.$, adjusted $R^{2}=0.058$, Figure 5C) community composition (Table 3 ). 


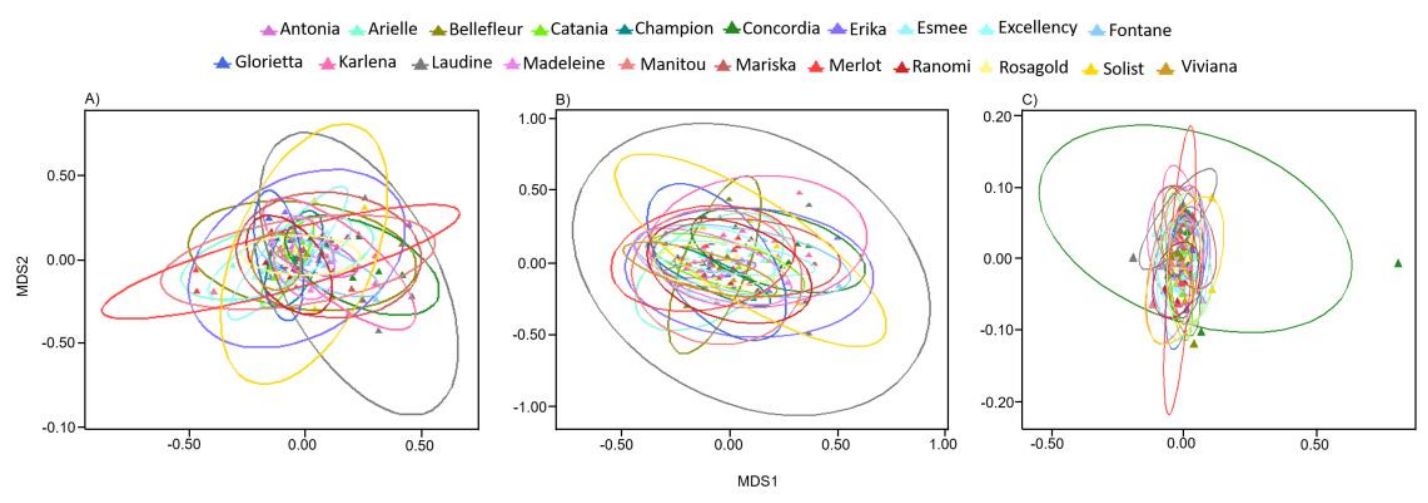

Figure 4. Non-metric multi-dimensional scaling, to model the effect of cultivar on root A) overall fungal-, B) pathogen-, and C) saprotroph community composition collected at different sampling points.
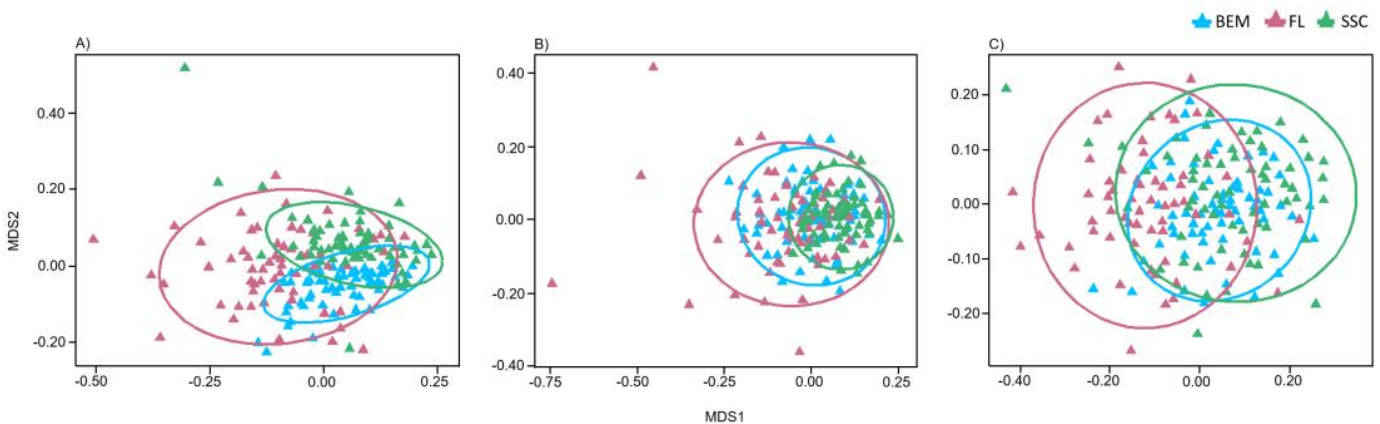

Figure 5. Non-metric multi-dimensional scaling, to model the effect of time on rhizosphere A) overall fungal-, B) pathogen-, C) saprotroph community composition collected at different sampling points. BEM, before emergence; FL, flowering stage; SSC, senescence stage.

\section{Discussion}

Plant rhizosphere offers habitat niches and root exudates as nutrients for microorganisms [37], [38]. In the present study, root samples contained only a fifth of the total OTUs detected, suggesting that few microorganisms overcome plant defense mechanisms and inhabit plant roots. Ascomycota was the most abundant phylum detected in roots for each studied time point. Furthermore, ascomycetes prevailed in the roots of all potato cultivars. Ascomycota is the most diverse fungal phylum, comprising the majority of plant pathogens [39]. Furthermore, ascomycetes have been shown to be the predominant organic matter taxon in agro-ecosystems [40]. Mortierellomycota, another dominant phylum in the rhizosphere, followed Ascomycota. This phylum includes, among others, the genus Mortierella, a main decomposing fungus in soil [41]. Furthermore, Mortierella spp. is known to contribute to soil phosphorus cycling [42].

Sampling time was the strongest variable shaping total fungal richness, both in rhizosphere and roots. The role of temporal change in both bacterial and fungal communities has been observed in other studies [43], [44], [45]. In the present study, overall root-fungal richness was highest in the plant FL stage; whereas in rhizosphere soil samples, overall fungal richness peaked during the SSC stage. These results imply that in intensively managed agricultural soil during the early stages of plant growth, fungi mainly colonise healthy plant roots, which may provide high amounts of energy to the fungi. In later stages, when pathogens accumulate and plants senesce, nutrient flow ceases. In addition, fungal community development (succession) during the growing season may also contribute to the observed temporal dynamics, possibly due to climatic conditions, time since disturbance (ploughing) and interactions between fungi. Furthermore, quality and quantity of root exudates may have been one underlying reason for the differences in total root-fungal richness and composition between cultivars. Previous studies have shown that plant genotypes differ in their root 
exudates, and this in turn can result in shifts in the structure of rhizosphere microbial communities [46], [47].

Root pathogen richness was mainly affected by plant cultivar, with lowest pathogen richness associated with cultivars Viviana, Solist and Concordia, which are considered relatively resistant cultivars with medium nutrient demand (Europlant.biz, Danespo.com). Roots of the cultivar Glorietta were the most susceptible to plant pathogens. However, higher pathogen richness may not always be related to higher disease incidence and severity. Moreover, pathogen higher richness can lead to microbial competition in the rhizosphere, and suppress the dominant plant pathogens [48]. Pathogen relative abundance in roots and rhizosphere did not differ among cultivars; these uniformly increased over the growing season, which is in agreement with Lemanczyk \& Sadowski [49]. These differences may be related to increases in fungal infection with host age.

Saprotroph richness in roots and rhizosphere peaked during the plant FL- and SSC stage, respectively; whereas saprotroph relative abundance in both rhizosphere and roots decreased in the plant SSC stage. Saprotroph richness-peaks in the FL stage could be attributed to increases in rhizodeposits [50]. The increase in saprotroph relative abundance can be explained by accumulating decaying material at the beginning of the plant growth period, as straw residues of cereal crops left in soil from earlier crop rotation stages start to decompose, and the amount of organic input increases.

Relative abundance of pathogens in roots and rhizosphere was mainly affected by the sampling time, with higher relative pathogen abundance in the plant SSC stage. Common in potato cultivation, and in the present study, harrowing or other physical disruptions are stopped from the beginning of flowering time until harvesting. In support of our findings, the abundance of many soil-borne pathogens increase to damaging levels under non-inversion tillage conditions[51], [52], [53]. In roots, cultivar also had a significant effect, with Rosagold being associated with significantly higher fungal pathogen abundance than Catania.

Relative saprotroph abundance in roots and rhizosphere was explained by the sampling time. In roots, plant FL stage exhibited significantly higher saprotroph abundance; and in rhizosphere, highest saprotroph abundance was observed at the BEM stage. Thus, it can be expected that continuous tillage operations at the beginning of the growth period, and resource-rich spring wheat residues, being relatively fibrous with more long-term decomposition, increased saprotrophic-fungal abundance in the BEM stage. Also, cultivar had a significant influence on rhizosphere saprotroph abundance, with Viviana having significantly higher saprotroph abundance than Manitou.

The dominant plant pathogens, both in root and rhizosphere, are common pathogens of potato, with capability for saprophytic growth and infective spread to other hosts. Plectosphaerella cucumerina prevailed both in rhizosphere and root samples, which is in agreement with previous studies in Italy [54], [55]. Although this pathogen causes wilting in potato [56], some studies have shown that $P$. cucumerina acts as a biocontrol agent against potato cyst nematodes [57]. Other abundant pathogens, belonging to genera such as Fusarium and Rhizoctonia, are common potato pathogens causing dry rot and black scurf, respectively. These soil-borne genera are among the most economically-important plant-pathogenic fungi, [58], [23], [59] and can survive saprophytically on crop residues in the absence of their hosts, growing rapidly when fresh organic matter is available [59]. When different crops susceptible to the same pathogens are grown in a field year after year, development and persistence of soil-borne pathogens is almost certain [23].

The abundance of most dominant pathogens increased over the growing season. This is in agreement with the generally-observed exponential increase in disease incidence of most crop pathogens over time during the growing season. It can be speculated that, in addition to changes in exudate patterns and root architecture, plants get older and their resistance against pathogens decreases, allowing dominant pathogens to prevail. In addition to temporal effects, the present study confirmed previous findings [60] regarding different cultivar susceptibilities to Rhizoctonia solani. Our results demonstrate that relative abundance of $R$. solani in plant roots is strongly affected by cultivar. Although Bains et al. [60] has shown that cultivars do not have complete resistance to this pathogen, our results revealed that some cultivars show almost no occurrence of $R$. solani when grown in the same soils where other cultivars became infected by this fungus. According to the breeding company 
(Norika $\mathrm{GmbH}$ ) information, the cultivar Merlot has high resistance to Rhizoctonia spp. Nevertheless, we found that Merlot showed marginally stronger abundance of $R$. solani than other cultivars. Furthermore, in this field trial, at the end of growing period, plants with nests of small-sized tubers caused by $R$. solani were only observed on Merlot.

Plant cultivar was the main factor affecting overall fungal-, pathogen- and saprotroph community composition in roots. It can be speculated that host genotype determined the fungal mycobiome recruited from the rhizosphere soil into the potato roots. Furthermore, a similar, consistent and weak, yet significant, effect of genotype on bacterial community composition in plant roots was observed in previous studies [61], [62], [63].

Fungal community composition in rhizosphere was affected by sampling time. The quality and quantity of organic substances change over time. Due to the several intensive tillage operations in the beginning of the growth period, decaying organic matter mixes with bulk soil, offering nutrients to specific fungal guilds. During the vegetative period, organic matter content decreases, and is replaced by root exudates. A previous study by Chaparro et al. [64] showed that the surrounding rhizosphere microbiome is affected by plant developmental stage, and is related to root exudation. Plants exude organic compounds into the surrounding environment [65], and microbes use these organic compounds as nutrients; and different microbial groups have distinct nutritional preferences [66]. Therefore, these qualitative changes in root exudation may cause differences in rhizosphere fungal community composition.

\section{Conclusions}

In this study, we assessed differences in fungal community structure in the roots and rhizosphere soil of 21 potato cultivars, and among different plant growth stages. Potato cultivars (genotypes) developed distinctive fungal communities in their roots, with the background of similar fungal assemblages in rhizosphere soil showing temporal changes over the growing season. The abundances of fungal guild representatives in roots of potato cultivars, as well as fungal guild composition and diversity, showed temporal changes. The occurrence of major pathogens strongly varied among potato cultivars. Overall, our results demonstrate that, in roots, cultivar was a primary factor determining overall fungal-, pathogen- and saprotroph community composition.

Author Contributions: Conceptualization, M.Ö., E.R.P., L.T. and K.L.; methodology, L.T., L.S. and K.L.; formal analysis, L.T., A.A., L.S. and K.L; data curation, L.S. and K.L; writing-original draft preparation, L.S., M.Ö, L.T., A.A. and K.L.; writing - review and editing, L.T., M.Ö., A.A., E.R.P.,L.S, K.L; visualisation, L.S, K.L.; funding acquisition, L.T, E.R.P., A.A., K.L. All authors have read and agreed to the published version of the manuscript.

Funding: This research was funded by Estonian Science Foundation grant no 9432, the European Regional Development Fund (project RESIST 3.2.0701.11-0003) and Center of Excellence EcolChange: Ecology of global change: natural and managed ecosystems), the Estonian University of Life Sciences project (base funding P190259PKTT), the Institutional Research Funding [project no. IUT36-2 of Estonian Research Council] and European Union's Horizon 2020 Research and Innovation Programme under Grant Agreement No 817819.

Acknowledgments: We thank R. Kiiker, K. Leitaru, S. Anslan, R. Puusepp and Einola Farm for technical support, and Jonathan Willow for language editing.

Conflicts of Interest: The authors declare no conflict of interest. The funders had no role in the design of the study; in the collection, analyses, or interpretation of data; in the writing of the manuscript, or in the decision to publish the results.

\section{References}

1. Lakshmanan, V.; Selvaraj, G.; Bais, H.P. Functional Soil Microbiome: Belowground Solutions to an Aboveground Problem. Plant Physiol. 2014, 166, 689-700, doi:10.1104/PP.114.245811.

2. de Vries, F.T.; Thébault, E.; Liiri, M.; Birkhofer, K.; Tsiafouli, M.A.; Bjørnlund, L.; Bracht Jørgensen, H.; Brady, M.V.; Christensen, S.; de Ruiter, P.C.; et al. Soil food web properties explain ecosystem services across European land use systems. Proc. Natl. Acad. Sci. U. S. A. 2013, 110, 14296-301, doi:10.1073/pnas.1305198110. 
3. Bardgett, R.D.; van der Putten, W.H. Belowground biodiversity and ecosystem functioning. Nature 2014, 515, 505-511, doi:10.1038/nature13855.

4. Philippot, L.; Raaijmakers, J.M.; Lemanceau, P.; van der Putten, W.H. Going back to the roots: the microbial ecology of the rhizosphere. Nat. Rev. Microbiol. 2013, 11, 789-799, doi:10.1038/nrmicro3109.

5. van der Heijden, M.G.A.; Bardgett, R.D.; van Straalen, N.M. The unseen majority: soil microbes as drivers of plant diversity and productivity in terrestrial ecosystems. Ecol. Lett. 2008, 11, 296-310, doi:10.1111/j.1461-0248.2007.01139.x.

6. Detheridge, A.P.; Brand, G.; Fychan, R.; Crotty, F. V.; Sanderson, R.; Griffith, G.W.; Marley, C.L. The legacy effect of cover crops on soil fungal populations in a cereal rotation. Agric. Ecosyst. Environ. 2016, 228, 49-61, doi:10.1016/J.AGEE.2016.04.022.

7. Francioli, D.; Schulz, E.; Lentendu, G.; Wubet, T.; Buscot, F.; Reitz, T. Mineral vs. Organic Amendments: Microbial Community Structure, Activity and Abundance of Agriculturally Relevant Microbes Are Driven by Long-Term Fertilization Strategies. Front. Microbiol. 2016, 7, 1446, doi:10.3389/fmicb.2016.01446.

8. Säle, V.; Aguilera, P.; Laczko, E.; Mäder, P.; Berner, A.; Zihlmann, U.; van der Heijden, M.G.A.; Oehl, F. Impact of conservation tillage and organic farming on the diversity of arbuscular mycorrhizal fungi. Soil Biol. Biochem. 2015, 84, 38-52, doi:10.1016/J.SOILBIO.2015.02.005.

9. Schmidt, R.; Mitchell, J.; Scow, K. Cover cropping and no-till increase diversity and symbiotroph:saprotroph ratios of soil fungal communities. Soil Biol. Biochem. 2019, 129, 99-109, doi:10.1016/J.SOILBIO.2018.11.010.

10. Soonvald, L.; Loit, K.; Runno-Paurson, E.; Astover, A.; Tedersoo, L. The role of long-term mineral and organic fertilisation treatment in changing pathogen and symbiont community composition in soil. Appl. Soil Ecol. 2019, 141, 45-53, doi:10.1016/J.APSOIL.2019.05.003.

11. Brader, G.; Compant, S.; Vescio, K.; Mitter, B.; Trognitz, F.; Ma, L.-J.; Sessitsch, A. Ecology and Genomic Insights into Plant-Pathogenic and Plant-Nonpathogenic Endophytes. Annu. Rev. Phytopathol. 2017, 55, 61-83, doi:10.1146/annurev-phyto-080516-035641.

12. Grayston, S.J.; Wang, S.; Campbell, C.D.; Edwards, A.C. Selective influence of plant species on microbial diversity in the rhizosphere. Soil Biol. Biochem. 1998, 30, 369-378, doi:10.1016/S0038-0717(97)00124-7.

13. Zimudzi, J.; van der Waals, J.E.; Coutinho, T.A.; Cowan, D.A.; Valverde, A. Temporal shifts of fungal communities in the rhizosphere and on tubers in potato fields. Fungal Biol. 2018, 122, 928-934, doi:10.1016/J.FUNBIO.2018.05.008.

14. BADRI, D. V.; VIVANCO, J.M. Regulation and function of root exudates. Plant. Cell Environ. 2009, 32, 666-681, doi:10.1111/j.1365-3040.2009.01926.x.

15. Canarini, A.; Kaiser, C.; Merchant, A.; Richter, A.; Wanek, W. Root Exudation of Primary Metabolites: Mechanisms and Their Roles in Plant Responses to Environmental Stimuli. Front. Plant Sci. 2019, 10, 157, doi:10.3389/fpls.2019.00157.

16. Wissuwa, M.; Mazzola, M.; Picard, C. Novel approaches in plant breeding for rhizosphere-related traits. Plant Soil 2009, 321, 409-430, doi:10.1007/s11104-008-9693-2.

17. Food and Agriculture Organization of the United Nations. FAOSTAT Database. Rome, Italy: FAO. Available online: http://www.fao.org/faostat/en/\#data/TP (accessed on Jun 3, 2020).

18. Fry, W.E.; Goodwin, S.B. Re-emergence of Potato and Tomato Late Blight in the United States. Plant Dis. 1997, 81, 1349-1357, doi:10.1094/PDIS.1997.81.12.1349.

19. Fry, W. Phytophthora infestans: the plant (and R gene) destroyer. Mol. Plant Pathol. 2008, 9, 385-402, 
doi:10.1111/j.1364-3703.2007.00465.x.

20. Toth, I.K.; van der Wolf, J.M.; Saddler, G.; Lojkowska, E.; Hélias, V.; Pirhonen, M.; Tsror Lahkim, L.; Elphinstone, J.G. Dickeya species: an emerging problem for potato production in Europe. Plant Pathol. 2011, 60, 385-399, doi:10.1111/j.1365-3059.2011.02427.x.

21. Zheng, Y.; Kim, Y.-C.; Tian, X.-F.; Chen, L.; Yang, W.; Gao, C.; Song, M.-H.; Xu, X.-L.; Guo, L.-D. Differential responses of arbuscular mycorrhizal fungi to nitrogen addition in a near pristine Tibetan alpine meadow. FEMS Microbiol. Ecol. 2014, 89, 594-605, doi:10.1111/1574-6941.12361.

22. Patil, V.U.; Girimalla, V.; Sagar, V.; Bhardwaj, V.; Chakrabarti, S.K. Draft Genome Sequencing of Rhizoctonia solani Anastomosis Group 3 (AG3- PT) Causing Stem Canker and Black Scurf of Potato. Am. J. Potato Res. 2018, 95, 87-91, doi:10.1007/s12230-017-9606-0.

23. Stefańczyk, E.; Sobkowiak, S.; Brylińska, M.; Śliwka, J. Diversity of Fusarium spp. associated with dry rot of potato tubers in Poland. Eur. J. Plant Pathol. 2016, 145, 871-884, doi:10.1007/s10658-016-0875-0.

24. Bakker, M.G.; Manter, D.K.; Sheflin, A.M.; Weir, T.L.; Vivanco, J.M. Harnessing the rhizosphere microbiome through plant breeding and agricultural management. Plant Soil 2012, 360, 1-13, doi:10.1007/s11104-012-1361-x.

25. Estonian Weather Service. Meteorological Yearbook of Estonia 2014. Available online: http://www.ilmateenistus.ee/wp-content/uploads/2013/01/aastaraamat_2014.pdf (accessed on Jun 10, 2020).

26. Egnér, H., Riehm, H., W.R.D. Untersuchungen über die chemische Bodenanalyse als Grundlage für die Beurteilung des Nährstoffzustandes der Böden. II. Chemische Extraktionsmethoden zur Phosphor- und Kaliumbestimmung. Kungliga Lantbrukshögskolans annaler 26. 1960, 199-215.

27. Hack, H., Gall, H., Klemke, T.H., Klose, R., Meier, U., Stauss, R., Witzenberger, A. The BBCH scale for phonological growth stages of potato (Solanum tuberosum L.). In: Meier, U. (Ed.), Growth Stages of Mono- and Dicotyledonous Plants, BBCH Monograph. Federal Biological Research Centre for Agriculture and Forestry, Berlin, Germany. 2001, 7-16.

28. Tedersoo, L.; Bahram, M.; Põlme, S.; Kõljalg, U.; Yorou, N.S.; Wijesundera, R.; Ruiz, L.V.; Vasco-Palacios, A.M.; Thu, P.Q.; Suija, A.; et al. Global diversity and geography of soil fungi. Science (80-. ). 2014, 346, doi:10.1126/science.1256688.

29. Schloss, P.D.; Westcott, S.L.; Ryabin, T.; Hall, J.R.; Hartmann, M.; Hollister, E.B.; Lesniewski, R.A.; Oakley, B.B.; Parks, D.H.; Robinson, C.J.; et al. Introducing mothur: open-source, platform-independent, community-supported software for describing and comparing microbial communities. Appl. Environ. Microbiol. 2009, 75, 7537-41, doi:10.1128/AEM.01541-09.

30. Masella, A.P.; Bartram, A.K.; Truszkowski, J.M.; Brown, D.G.; Neufeld, J.D. PANDAseq: paired-end assembler for illumina sequences. BMC Bioinformatics 2012, 13, 31, doi:10.1186/1471-2105-13-31.

31. Edgar, R.C. Search and clustering orders of magnitude faster than BLAST. Bioinformatics 2010, 26, 24602461, doi:10.1093/bioinformatics/btq461.

32. Bengtsson-Palme, J.; Ryberg, M.; Hartmann, M.; Branco, S.; Wang, Z.; Godhe, A.; De Wit, P.; SánchezGarcía, M.; Ebersberger, I.; de Sousa, F.; et al. Improved software detection and extraction of ITS1 and ITS2 from ribosomal ITS sequences of fungi and other eukaryotes for analysis of environmental sequencing data. Methods Ecol. Evol. 2013, 4, n/a-n/a, doi:10.1111/2041-210X.12073.

33. Fu, L.; Niu, B.; Zhu, Z.; Wu, S.; Li, W. CD-HIT: accelerated for clustering the next-generation sequencing data. Bioinformatics 2012, 28, 3150-2, doi:10.1093/bioinformatics/bts565.

34. Kõljalg, U.; Tedersoo, L.; Nilsson, R.H.; Abarenkov, K. Digital identifiers for fungal species. Science 2016, 
352, 1182-3, doi:10.1126/science.aaf7115.

35. Nguyen, N.H.; Song, Z.; Bates, S.T.; Branco, S.; Tedersoo, L.; Menke, J.; Schilling, J.S.; Kennedy, P.G. FUNGuild: An open annotation tool for parsing fungal community datasets by ecological guild. Fungal Ecol. 2016, 20, 241-248, doi:10.1016/J.FUNECO.2015.06.006.

36. Anderson, M.J., Gorley, R.N., Clarke, K.R. PERMANOVA+ for PRIMER: Guide to Software and Statistical Methods. PRIMER-E, Plymouth, UK. 2008.

37. Guyonnet, J.P.; Cantarel, A.A.M.; Simon, L.; Haichar, F. el Z. Root exudation rate as functional trait involved in plant nutrient-use strategy classification. Ecol. Evol. 2018, 8, 8573-8581, doi:10.1002/ece3.4383.

38. Haichar, F. el Z; Santaella, C.; Heulin, T.; Achouak, W. Root exudates mediated interactions belowground. Soil Biol. Biochem. 2014, 77, 69-80, doi:10.1016/J.SOILBIO.2014.06.017.

39. Agrios, G.N. Plant pathology; 5th ed.; Elsevier Academic Press, USA, 2005; ISBN 9780120445653.

40. Ma, A.; Zhuang, X.; Wu, J.; Cui, M.; Lv, D.; Liu, C.; Zhuang, G. Ascomycota members dominate fungal communities during straw residue decomposition in arable soil. PLoS One 2013, 8, e66146, doi:10.1371/journal.pone.0066146.

41. Li, F.; Chen, L.; Redmile-Gordon, M.; Zhang, J.; Zhang, C.; Ning, Q.; Li, W. Mortierella elongata's roles in organic agriculture and crop growth promotion in a mineral soil. L. Degrad. Dev. 2018, 29, 1642-1651, doi:10.1002/ldr.2965.

42. Osorio, N.W.; Habte, M. Synergistic Influence of an Arbuscular Mycorrhizal Fungus and a P Solubilizing Fungus on Growth and P Uptake of Leucaena leucocephala in an Oxisol. Arid L. Res. Manag. 2001, 15, 263274, doi:10.1080/15324980152119810.

43. Inceoğlu, O.; Salles, J.F.; van Overbeek, L.; van Elsas, J.D. Effects of plant genotype and growth stage on the betaproteobacterial communities associated with different potato cultivars in two fields. Appl. Environ. Microbiol. 2010, 76, 3675-84, doi:10.1128/AEM.00040-10.

44. Schlemper, T.R.; Leite, M.F.A.; Lucheta, A.R.; Shimels, M.; Bouwmeester, H.J.; van Veen, J.A.; Kuramae, E.E. Rhizobacterial community structure differences among sorghum cultivars in different growth stages and soils. FEMS Microbiol. Ecol. 2017, 93, doi:10.1093/femsec/fix096.

45. Gao, C.; Montoya, L.; Xu, L.; Madera, M.; Hollingsworth, J.; Purdom, E.; Hutmacher, R.B.; Dahlberg, J.A.; Coleman-Derr, D.; Lemaux, P.G.; et al. Strong succession in arbuscular mycorrhizal fungal communities. ISME J. 2019, 13, 214-226, doi:10.1038/s41396-018-0264-0.

46. Van Overbeek, L.; Van Elsas, J.D. Effects of plant genotype and growth stage on the structure of bacterial communities associated with potato (Solanum tuberosum L.). FEMS Microbiol. Ecol. 2008, 64, 283-296, doi:10.1111/j.1574-6941.2008.00469.x.

47. van Dam, N.M.; Bouwmeester, H.J. Metabolomics in the Rhizosphere: Tapping into Belowground Chemical Communication. Trends Plant Sci. 2016, 21, 256-265, doi:10.1016/J.TPLANTS.2016.01.008.

48. Pérez-Piqueres, A.; Edel-Hermann, V.; Alabouvette, C.; Steinberg, C. Response of soil microbial communities to compost amendments. Soil Biol. Biochem. 2006, 38, 460-470, doi:10.1016/J.SOILBIO.2005.05.025.

49. Lemanczyk, G.; Sadowski, C.K. Fungal communities and health status of roots of winter wheat cultivated after oats and oats mixed with other crops. BioControl 2002, 47, 349-361, doi:10.1023/A:1014890826149.

50. Kaiser, C.; Kilburn, M.R.; Clode, P.L.; Fuchslueger, L.; Koranda, M.; Cliff, J.B.; Solaiman, Z.M.; Murphy, D. V. Exploring the transfer of recent plant photosynthates to soil microbes: mycorrhizal pathway vs direct root exudation. New Phytol. 2015, 205, 1537-1551, doi:10.1111/nph.13138. 
51. Bockus, W.W.; Shroyer, J.P. The impact of reduced tillage on soilborne plant pathogens. Annu. Rev. Phytopathol. 1998, 36, 485-500, doi:10.1146/annurev.phyto.36.1.485.

52. Bailey, K..; Lazarovits, G. Suppressing soil-borne diseases with residue management and organic amendments. Soil Tillage Res. 2003, 72, 169-180, doi:10.1016/S0167-1987(03)00086-2.

53. Friberg, H.; Persson, P.; Jensen, D.F.; Bergkvist, G. Preceding crop and tillage system affect winter survival of wheat and the fungal communities on young wheat roots and in soil. FEMS Microbiol. Lett. 2019, 366, doi:10.1093/femsle/fnz189.

54. Carlucci, A.; Raimondo, M.L.; Santos, J.; Phillips, A.J.L. Plectosphaerella species associated with root and collar rots of horticultural crops in southern Italy. Persoonia - Mol. Phylogeny Evol. Fungi 2012, 28, 34-48, doi:10.3767/003158512X638251.

55. Raimondo, M.L.; Carlucci, A. Characterization and pathogenicity assessment of Plectosphaerella species associated with stunting disease on tomato and pepper crops in Italy. Plant Pathol. 2018, 67, 626-641, doi:10.1111/ppa.12766.

56. Gao, J.; Zhang, Y.Y.; Zhao, X.J.; Wang, K.; Zhao, J. First Report of Potato Wilt Caused by Plectosphaerella cucumerina in Inner Mongolia, China. Plant Dis. 2016, 100, 2523, doi:10.1094/PDIS-01-16-0028-PDN.

57. Atkins, S.D.; Clark, I.M.; Sosnowska, D.; Hirsch, P.R.; Kerry, B.R. Detection and quantification of Plectosphaerella cucumerina, a potential biological control agent of potato cyst nematodes, by using conventional PCR, real-time PCR, selective media, and baiting. Appl. Environ. Microbiol. 2003, 69, 478893, doi:10.1128/aem.69.8.4788-4793.2003.

58. Tsror, L. Biology, Epidemiology and Management of Rhizoctonia solani on Potato. J. Phytopathol. 2010, 158, 649-658, doi:10.1111/j.1439-0434.2010.01671.x.

59. Leplat, J.; Friberg, H.; Abid, M.; Steinberg, C. Survival of Fusarium graminearum, the causal agent of Fusarium head blight. A review. Agron. Sustain. Dev. 2013, 33, 97-111, doi:10.1007/s13593-012-0098-5.

60. Bains, P.S.; Bennypaul, H.S.; Lynch, D.R.; Kawchuk, L.M.; Schaupmeyer, C.A. Rhizoctonia disease of potatoes (Rhizoctonia solani): Fungicidal efficacy and cultivar susceptibility. Am. J. Potato Res. 2002, 79, 99-106, doi:10.1007/BF02881518.

61. Lundberg, D.S.; Lebeis, S.L.; Paredes, S.H.; Yourstone, S.; Gehring, J.; Malfatti, S.; Tremblay, J.; Engelbrektson, A.; Kunin, V.; Rio, T.G. del; et al. Defining the core Arabidopsis thaliana root microbiome. Nature 2012, 488, 86-90, doi:10.1038/nature11237.

62. García de León, D.; Vahter, T.; Zobel, M.; Koppel, M.; Edesi, L.; Davison, J.; Al-Quraishy, S.; Hozzein, W.N.; Moora, M.; Oja, J.; et al. Different wheat cultivars exhibit variable responses to inoculation with arbuscular mycorrhizal fungi from organic and conventional farms. PLoS One 2020, 15, e0233878, doi:10.1371/journal.pone.0233878.

63. Bokulich, N.A.; Thorngate, J.H.; Richardson, P.M.; Mills, D.A. Microbial biogeography of wine grapes is conditioned by cultivar, vintage, and climate. Proc. Natl. Acad. Sci. U. S. A. 2014, 111, E139-48, doi:10.1073/pnas.1317377110.

64. Chaparro, J.M.; Badri, D. V; Vivanco, J.M. Rhizosphere microbiome assemblage is affected by plant development. ISME J. 2014, 8, 790-803, doi:10.1038/ismej.2013.196.

65. Nguyen, C. Rhizodeposition of organic C by plants: mechanisms and controls. Agron. EDP Sci. 2003, 23 (5-6), 375-396.

66. Chaparro, J.M.; Badri, D. V.; Bakker, M.G.; Sugiyama, A.; Manter, D.K.; Vivanco, J.M. Root Exudation of Phytochemicals in Arabidopsis Follows Specific Patterns That Are Developmentally Programmed and Correlate with Soil Microbial Functions. PLoS One 2013, 8, e55731, doi:10.1371/journal.pone.0055731. 
19 of 19 